\title{
Interventions to Promote a Healthy Sexuality among School Adolescents: A Scoping Review
}

\author{
Fernanda Loureiro *(D), Margarida Ferreira (D), Paula Sarreira-de-Oliveira (D) and Vanessa Antunes (D) \\ Centro de Investigação Interdisciplinar Egas Moniz (CiiEM), Escola Superior de Saúde Egas Moniz, \\ 2829-511 Almada, Portugal; mferreira@egasmoniz.edu.pt (M.F.); psarreira@egasmoniz.edu.pt (P.S.-d.-O.); \\ vantunes@egasmoniz.edu.pt (V.A.) \\ * Correspondence: floureiro@egasmoniz.edu.pt; Tel.: +351-212-946-807
}

Citation: Loureiro, F.; Ferreira, M.; Sarreira-de-Oliveira, P.; Antunes, V. Interventions to Promote a Healthy Sexuality among School Adolescents: A Scoping Review. J. Pers. Med. 2021, 11, 1155. https://doi.org/10.3390/ jpm11111155

Academic Editor: Ruslan Dorfman

Received: 7 September 2021

Accepted: 4 November 2021

Published: 7 November 2021

Publisher's Note: MDPI stays neutral with regard to jurisdictional claims in published maps and institutional affiliations.

Copyright: (c) 2021 by the authors. Licensee MDPI, Basel, Switzerland. This article is an open access article distributed under the terms and conditions of the Creative Commons Attribution (CC BY) license (https:/ / creativecommons.org/licenses/by/ $4.0 /)$.
Abstract: Schools are particularly suitable contexts for the implementation of interventions focused on adolescent sexual behavior. Sexual education and promotion have a multidisciplinary nature. Nurses' role and the spectrum of the carried-out interventions is not clear. We aimed to identify interventions that promote a healthy sexuality among school adolescents. Our review followed the Preferred Reporting Items for Systematic Reviews and Meta-Analyses extension for Scoping Reviews and was registered in the Open Science Framework. Published articles on sexuality in adolescents in school contexts were considered. The research limitations included primary studies; access in full text in English, Spanish, or Portuguese; and no data publication limitation. Research was carried out on the EBSCOhost, PubMed, SciELO, and Web of Science platforms; gray literature and the bibliographies of selected articles were also searched. A total of 56 studies were included in the sample. The studies used a broad range of research methods, and 10 types of interventions were identified. Multi-interventional programs and socio-emotional interventions showed a greater impact on long-term behavioral changes, and continuity seemed to be a key factor. Long-term studies are needed to reach a consensus on the effectiveness of interventions. Nurses' particular role on the multidisciplinary teams was found to be a gap in the research, and must be further explored.

Keywords: adolescent; nursing; review literature; sexuality

\section{Introduction}

The World Health Organization [1] considers sexuality as a central aspect of human beings. It is influenced by psychological, social, biological, religious, spiritual, political, legal, economic, ethical, and historical issues.

Sexual development is considered a multidimensional process that is experienced more intensely by adolescents as they go through the changes of puberty, develop the capacity for intimacy, and experience sexual thoughts [2]. Adolescence is a complex stage of life that brings several challenges to health professionals. By traditional definition, it includes individuals from 10 to 19 years old. However, the definition has long posed a conundrum, and recently Sawyer at al. [3] suggested an extension to 10-24 years to correspond to a more current and updated concept. Regardless of age limits, it is a period of important biological growth, psychological development, and social role transitions.

The World Health Organization and other agencies consider sexual education as a priority within this age group due to sexual behavior implications, such as maternal mortality or sexually transmitted infections [4], and aspects such as gender-based violence and gender inequality. Since sexuality is an all-encompassing concept, there is no consensual definition of it. However, Goettsch [5] suggested a preliminary definition that includes: sexuality as an individual capacity, its experiential nature, body-oriented, and directed to genital excitation. The World Health Organization [1] gives a more comprehensive definition of sexuality that includes reproduction, sex, sexual orientation, gender identities 
and roles, pleasure, and intimacy, highlighting that not all of them are always experienced or expressed.

For many years now, schools have been considered privileged contexts for the implementation of health promotion and education, as they are built to foster personal and social development. Schools are the ideal place for building health-promoting communities, and are able to link children, families, and communities with other services (e.g., health services). The role of schools in health promotion is not a new phenomenon. In fact, historically, implementing health education interventions in schools has been recommended by several organizations and in several countries [6].

School-based education includes sexuality in its educational curricula, which is different from interventions, that can be implemented in a more/less structured way. Both approaches are used worldwide according to the context characteristics. School-based interventions are wildly recognized for their impact on adolescents' sexual health [6]. Many sex education programs, especially those centered on risks associated with sexual activity, focus on knowledge as a prerequisite for adopting preventive behaviors. However, results from surveys such as the Health Behavior in School-Aged Children showed a trend of systematic reduction in terms of knowledge and protective behaviors [7]. Simultaneously, scientific evidence has shown that existing knowledge is not directly expressed in preventive practices, and that programs that include an ecological and participatory approach are more effective [8]. Thus, the focus of intervention programs has been expanding at different levels: from risk prevention to well-being, from directed and specific to individual to comprehensive and structural, and from traditional knowledge transference to innovative tools [9].

Interventions such as school policy changes, parent involvement, and work with local communities have been identified as effective for promoting sexual health [10]. In addition, the influence of contextual factors such as peers, parents, siblings, and schools have been examined and established by researchers [11]. As the field of intervention has expanded, it became evident that sexual education and promotion has a multidisciplinary and crosssectoral nature. Interventions are broad, and are implemented by different professionals such as teachers, social workers, or psychologists, among others.

In this context, nurses are often involved in schools' health promotion programs in general, but their role in these programs is not always clear or visible. Depending on the different realities, they can be in school-based health centers, or work in partnership with teachers or as part of multidisciplinary school health teams, and are often the only link between children and the health system [12]. They work directly with children and adolescents, but also collaborate in the training of teachers and other school personnel [13]. Additionally, annual preventive health examinations are seen as encounters in which screening adolescents for sexual and reproductive health is recommended [14]. Nurses work in a wide variety of settings (hospitals, health centers, schools), which gives them direct access to adolescent populations. In addition, nurses have an important role in promoting accessibility, inclusive communication, competent and guideline-based care, and confidentiality. Barriers to the implementation of health programs, identified by teachers, include lack of training and lack of time [8]. The integration of nurses in these programs represents an added value, and their unique combination of knowledge and specific skills [14] make them an essential and central element in these teams. A preliminary literature search revealed that the available studies on sexual education interventions are dispersed. Specific studies on nursing interventions in the school context also are scarce. The role of nursing and its unique contributions to this area remain less clear and less explored. Therefore, it is fundamental to firstly map the wide spectrum of interventions to promote adolescent sexuality, carried out in the school context. This can further contribute to a clearer identification of nursing's role, and to the planning of interventions that are scientifically accurate, sustainable, and age- and culturally appropriate.

A scoping review was conducted according to the steps defined by Tricco et al. [15] that aimed to identify interventions that promote a healthy sexuality among school ado- 
lescents. This methodology proved to be advantageous, as it allowed identifying gaps in the literature, mapping the available evidence [16] that will support the planning of interventions to promote a healthy sexuality among adolescents in schools. The following research question was defined, according to PICo: which are the interventions that promote a healthy sexuality among school adolescents? (Population: adolescents; Interest: interventions to promote a healthy sexuality; Context: school).

\section{Materials and Methods}

The steps defined by Tricco et al. [15] for the scoping review were followed as detailed below.

Protocol and Registration. The protocol was drawn according to the Preferred Reporting Items for Systematic Reviews and Meta-Analyses extension for Scoping Reviews (PRISMA-ScR) and registered prospectively with the Open Science Framework on 18 June 2021 (https:/ /osf.io/v97ek/?view_only=).

Eligibility criteria. Considering the scarcity of studies on specific nursing interventions, and keeping in mind the multidisciplinary scope of health promotion, for the purposes of this study, we selected studies focused on multidisciplinary interventions. Published articles on nurses, teachers, psychologists, and social care professionals integrated in work groups on sexuality in adolescents from school context were considered for analysis. Empirical studies with quantitative, qualitative, and mixed methods were included to maximize the coverage of evidence available. Peer-reviewed papers available in open access and full text and written in English, Spanish, and Portuguese were included. As to the publication date, no time frame was established. Manuscripts were excluded if studies were performed in specific contexts and specific health conditions (for example, hospitalization or adolescents with mental disorders). Letters to the editor, editorials, literature reviews, theoretical studies, protocols, methodological studies (for example, instrument validation/construction), blog articles, advertising, and opinion articles were excluded. Studies in which subjects were family members or health professionals that did not identify or suggest any interventions were also excluded.

Information sources. A three-step approach was used, as recommended in the literature [17]. The search was initially performed in two databases: Medical Literature Analysis and Retrieval System Online (MEDLINE) and Cumulative Index to Nursing and Allied Health Literature (CINAHL). Then, an analysis of the words contained in the titles and summaries was performed to understand the best terms to be used in the review. The purpose was to identify the keywords to be included in search equation.

In step two, after identifying the MeSH keywords to be used, research was conducted on the electronic platform EBSCOhost in the following databases: Cumulative Index to Nursing and Allied Health Literature (CINAHL) (complete); MEDLINE (complete); Nursing \& Allied Health Collection (comprehensive); Cochrane Central Register of Controlled Trials; Cochrane Database of Systematic Reviews; Cochrane Methodology Register; Library, Information Science \& Technology Abstracts (LISTA); and MedicLatina. Additionally, PubMed, SciELO, ScienceDirect, and Web of Science were also searched. For grey literature, we used Open Grey, MedNar, and WorldWideScience.org-The Global Science Gateway.

In step three, the list of references from the articles selected in step two were systematically searched to find additional relevant literature for this review.

Search. The research equation, designed with keywords and Boolean operators, was: ((Adolescen *) AND (Sexuality) AND (Nurs *)). An asterisk operator $\left({ }^{*}\right)$ was used, so that the database could identify variants of the original word. Research was performed in March 2021 by all the authors, working in groups of two (F.L. and V.A.; P.O. and M.F.). Considering inclusion criteria and fields available in databases, the sample initially obtained was limited, as shown in Table A1 (Appendix A).

Selection of sources of evidence. Articles were selected initially by title, and when it was not clear if the article fitted this review, the abstract was read. Duplicates were removed, and inclusion/exclusion criteria were applied. Reviewers in groups of two 
(F.L. and P.O.; V.A. and M.F.) screened the same publications to increase consistency. Any disagreements between reviewers were resolved through discussion with all reviewers until consensus was reached.

Data-charting process. The variables to be extracted were decided by all researchers, and a data-charting table was developed. The process was initially performed individually by each author. Then, working groups of two were formed (F.L. and P.O.; V.A. and M.F.) to compare the extracted data, resolve disagreements, and increase accuracy. In cases in which the articles contained insufficient information, the authors were contacted. The final extraction chart was discussed by all authors until reaching unanimity.

Data items. Data were extracted related to article characteristics such as reference, country, and methods (aim, population and sample, type of study). We also included the intervention implemented, as well as the main findings.

Critical appraisal of individual sources of evidence. To describe the quality of the selected articles $(n=56)$, studies were appraised by all authors. Divergent views regarding the critical appraisal were reviewed until consensus. The Hawker et al. [18] assessment tool, with a four-grade scale $(1=$ very poor; 2 = poor; $3=$ fair; 4 = good $)$ was used. The total score ranges between 9 and 36, and higher scores indicate higher quality. An article's quality appraisal was centered on the following items: 1 -abstract and title; 2 -introduction and aims; 3-method and data; 4-sampling; 5-data analysis; 6-ethics and bias; 7-results; 8-transferability or generalizability; and 9-implications and usefulness.

Synthesis of results. Results were synthetized in a table that included all information extracted individually and approved by all authors. The data collected summarized studies and interventions that were identified in this review. Information was collected related to article reference, country where the study was applied, methods, intervention, and findings.

\section{Results}

Selection of sources of evidence. A total of 149 articles were identified by title. From those, 93 were excluded by abstract. Articles excluded were mainly those that did not identify interventions. Manuscripts that presented only data concerning descriptive statistics for a diagnostic purpose in a particular context were also excluded. The process of study selection is summarized below in Figure 1 using a PRISMA flow chart.

Characteristics of sources of evidence. This review allowed the identification of a broad set of interventions to promote a healthy sexuality among adolescents in the school context. Through the International Classification of Health Interventions (ICHI), the World Health Organization [19] defines a health intervention as an act that has the purpose of assessing, improving, maintaining, promoting, or modifying health, functioning, or health conditions. These interventions can be performed for, with, or on behalf of a person or population. According to ICHI descriptors, interventions regarding sexuality can be mostly framed as interventions on body systems and function (ICHI code 1) or interventions on health-related behaviors (ICHI code 4). In this review, both types were retrieved from articles; however, interventions predominantly were oriented toward behaviors. On the other hand, it was not always clear which type of intervention was implemented; therefore, we categorized them as presented in Table A2 (Appendix A). The interventions were grouped by ascending order of frequency found in sample studies $(n=56)$.

Critical appraisal within sources of evidence. The results demonstrated that overall, the studies' quality was high. Quality appraisal ranged from 18 to 35. Sampling, ethics, and bias, as well as transferability, were the main limitations of the studies (Table A3Appendix A).

Results of individual sources of evidence. The results from each study selected in this scoping review are synthetized in Table A4 (Appendix A). 

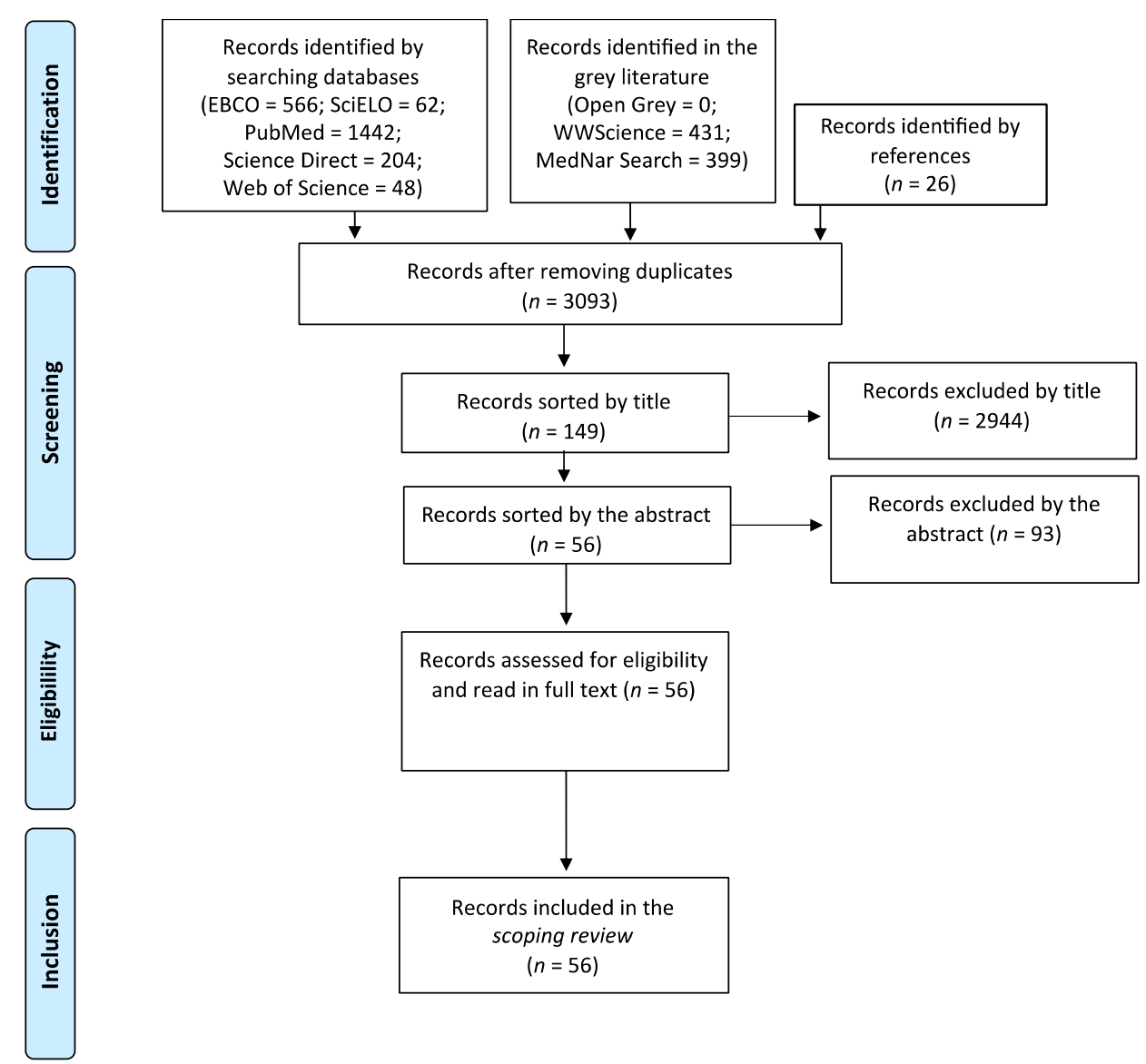

Figure 1. PRISMA flow chart of the study selection.

Synthesis of results. A total of 56 studies published between 1998 and 2021 were selected for final analysis. All studies had adolescents as subjects except for Barnes et al. [20], who studied nurses; and Valli and Cogo [21], whose study was related to school blogs on sexuality. Sample sizes ranged from 10 [22] to 11840 [23]. As to publication date, more than half of our article sample $(n=32)$ were published in the last 10 years. Regarding the country where studies were applied, we verified that there were studies from all around the world; however, three countries stood out: Brazil, with 16 articles; the USA, with 13 articles; and the UK, with 6 articles. Of the studies, 32 were of a quantitative nature, 18 used a qualitative approach, and 6 used mixed methods. Surveys were the most used form of collecting data (28), followed by combined techniques. These techniques included the use of surveys combined with interviews [24-26], focus groups [27,28], and an online environment [29]. A field diary and participating observation were also found as combined data collection techniques [22,30].

\section{Discussion}

Summary of evidence. The results indicated that adolescent sexuality is a relevant, current, and growing interest theme for health professionals, as we found articles from all around the world, and the great majority were recently published.

Evidence was mapped regarding the type of interventions performed in the school context, the factors that may influence their effectiveness, and a few considerations that were found on the multidisciplinary nature of school-based interventions.

Although studies that described an isolated intervention were found, mostly articles reported the findings of multiple interventional programs, such as SHARE [31-33] and Cuídate [34-36], or combined interventions, as stated above. The diversity of interventions 
found also reinforced the idea that adolescent health is still an evolving area [37] that requires a multidisciplinary approach.

Innovative approaches were also described, such as the use of blogs [21], Facebook [29], and online games $[27,38]$, as they seemed to have greater acceptance by adolescents. As technologies continue to expand, online resources are becoming progressively relevant and used by adolescents, which raises concerns regarding vulnerability, but also presents opportunities for important impacts on healthy learning [39].

Interestingly, mobile phone intervention was found in six studies. Given the access and amount of time spent by adolescents with these devices, this intervention seems particularly suitable for the adolescent population. As an intervention that uses existing resources, mobile phone intervention is cost effective and sustainable, with the ability to reach many adolescents even in low-income countries. Furthermore, there is evidence that the use of mobile text messages may lead to improved adolescent sexual and reproductive health [40].

Interventions delivered through school-based health centers (SBHCs) are described in two studies. The existence of SBHCs has proven to have an impact on adolescents regarding satisfaction with their health and adherence to health-promoting behaviors [41]. Not all countries have SBHCs, since they are not part of their health and education systems. Nevertheless, policy makers should consider including this strategy in their agendas, as it is a more comprehensive and integrated approach. It has proven to raise adolescents' access to health care services, overcoming identified barriers such as charges, transportation, accessibility, availability, and privacy concerns [23].

Sex education sessions, group discussions, and workshops can be framed as the more traditional interventions. They can be implemented alone, simultaneously, integrated in a broader program, or used combined with other interventions. The studies that addressed them were mostly descriptive, with few considerations of their effectiveness as isolated interventions. With respect to sex education sessions, nurses often have a prominent role, particularly school nurses, as they have a broader knowledge of health-related issues. Brewin et al. [42] reported barriers related to privacy, time, confidentiality, and fear of conflict.

Peer education was only mentioned in four studies. This is an intervention that creates greater expectations around its impact on adolescent sexual behavior because, when performed and conveyed by peers with a similar age or status, it becomes more appealing and credible [43]. However, no study could demonstrate peer education effectiveness by itself. Stephenson et al. [43] argued that it should be considered as part of a broader program.

Concerning interventions' effectiveness, some studies did not assess interventions' impact on adolescent behavior or knowledge, only describing the implementation experience in the school context. Even so, a more comprehensive approach that includes multiple types of interventions seems to be more effective in promoting positive changes in sexual behavior [44]. These findings were aligned with the multidimensional scope of adolescent sexuality.

In general, the articles evaluating the effectiveness of programs demonstrated a very low sustainability in the modification of risk behaviors $[31,36,43,45,46]$ of young people and adolescents. Of the articles included, only one showed maintenance of the positive effects in terms of reduced pregnancies, delayed sexual debut, and intentions to use condoms. Again, it described a more comprehensive approach: a training intervention for children's social competence, classroom management and instruction, and parenting practices without interventions specifically aimed at sexuality [47].

In addition, interventions focused on psycho-affective and socio-emotional skills showed a greater impact on long-term behavioral changes. These findings were in line with the growing interest in socio-emotional skills learning (SEL) that, especially since the beginning of this century, has shown a positive impact on school success, well-being, and health of the participants [48], and which are at the base of health-promotion programs in schools such as the Collaborative for Academic, Social, and Emotional Learning 
(CASEL) (Chicago, IL, USA) or the Schools for Health in Europe Network Foundation (SHE) (Haderslev, Denmark).

Furthermore, we believe that the fact that programs are mostly implemented in local and regional contexts and only in a specific period of time limits their long-term effectiveness. Continuity seems to be a key factor in maintaining the change in adolescent behavior with regard to their sexuality.

The fact that so many studies and so many different interventions were found, with little evidence of their effectiveness, may also signify a difficulty in officially instituting and operationalizing them in the long term.

It is worth noting the difficulties in categorizing the domains of sexuality and standardizing the language regarding interventions. Despite the evident effort of the scientific community, there is still no universal consensus on them. Thus, there seems to be agreement on the multidisciplinary nature of interventions that promote adolescent sexuality.

As to limitations, we must consider the possibility of having excluded or missed some relevant studies due to the databases used, and the exclusion of studies written in languages other than English, Spanish, or Portuguese.

\section{Conclusions}

As previously mentioned, nurses are often involved in schools' health-promotion programs in general, but their role in these programs is not always clear or visible. This research did not allow us to draw conclusions about this topic. Nonetheless, it is interesting to note that most studies had nurses or nursing professors as their first author, although they did not focus exclusively on the role of nurses/nursing care. Again, this can be explained by the multidisciplinary nature of the interventions.

Finding which interventions worked best to promote a healthy sexuality among school adolescents was challenging. As the studies were carried out in very different contexts, and there are few long-term evaluations of the implemented interventions, it was not possible to make considerations about their effectiveness.

This review allowed the identification of interventions implemented in schools to promote adolescents' healthy sexuality; namely, event history calendar, group discussion, interventions delivered through SBHC, peer education, online intervention, mobile phone intervention, combined interventions, workshops, sex education sessions, and multiple interventional programs. These findings were in line with the multidimensional scope of adolescent sexuality. The studies found were recent and were published all around the world, which sustained the idea that this is a relevant and evolving theme.

Although most authors were nursing professionals or nursing students, the particular role of nurses on the multidisciplinary team was not explored. This is clearly a gap in the evidence that requires further investigation. However, this review gave a clear picture of the interventions that can be implemented to promote adolescent sexuality. The effectiveness of those strategies should be further explored. Decision makers should integrate these strategies in their agendas and use them as collaboration measures between the health and education sectors.

Author Contributions: Conceptualization, F.L., M.F., P.S.-d.-O. and V.A.; methodology, F.L., M.F., P.S.-d.-O. and V.A.; software, F.L., M.F., P.S.-d.-O. and V.A.; validation, F.L., M.F., P.S.-d.-O. and V.A.; formal analysis, F.L., M.F., P.S.-d.-O. and V.A.; investigation, F.L., M.F., P.S.-d.-O. and V.A.; resources, F.L., M.F., P.S.-d.-O. and V.A.; data curation, F.L., M.F., P.S.-d.-O. and V.A; writing-original draft preparation, F.L.; writing - review and editing, M.F., P.S.-d.-O. and V.A.; visualization, F.L., M.F., P.S.-d.-O. and V.A.; supervision, F.L., M.F., P.S.-d.-O. and V.A.; project administration, F.L., M.F., P.S.-d.-O. and V.A.; funding acquisition, F.L., M.F., P.S.-d.-O. and V.A. All authors have read and agreed to the published version of the manuscript.

Funding: This work was financed by national funds through the FCT-Foundation for Science and Technology, I.P., under the project UIDB/04585/2020. The researchers would like to thank the Centro de Investigacão Interdisciplinar Egas Moniz (CiiEM) for the support provided for the publication of this article. 
Institutional Review Board Statement: The study was conducted according to the guidelines of the Declaration of Helsinki, and registered prospectively with the Open Science Framework on 18 June 2021 (https:/ / osf.io/v97ek/?view_only=).

Conflicts of Interest: The authors declare no conflict of interest.

\section{Appendix A}

Table A1. Platforms and limiters used in search strategy.

\begin{tabular}{|c|c|}
\hline Platform & Limiters \\
\hline \multirow{3}{*}{ EBSCOhost } & Adolescen * AND Sexuality AND Nurs * \\
\hline & Portuguese, Spanish, or English language full text available \\
\hline & Adolescen * AND Sexuality AND nurs * \\
\hline \multirow[t]{2}{*}{ PubMed } & Portuguese, Spanish, or English language \\
\hline & Full text available \\
\hline SciELO & $\begin{array}{l}\text { Adolescente OR adolescência AND sexualidade AND } \\
\text { enfermagem }\end{array}$ \\
\hline \multirow[t]{2}{*}{ ScienceDirect } & $\begin{array}{l}\text { (Adolescent OR Adolescence) AND Sexuality AND (nursing OR nurse) } \\
\text { Open access }\end{array}$ \\
\hline & Adolescen * AND Sexuality AND nurs * \\
\hline Web of Science & $\begin{array}{l}\text { Portuguese, Spanish, or English language } \\
\text { Full text available }\end{array}$ \\
\hline Open Grey & Adolescen * AND Sexuality AND nurs * \\
\hline MedNar & $\begin{array}{l}\text { Adolescen * AND Sexuality AND nurs * } \\
\text { Full text available }\end{array}$ \\
\hline WorldWideScience & $\begin{array}{l}\text { (Adolescent OR Adolescence) AND Sexuality AND (nursing OR nurse) } \\
\text { Full text available }\end{array}$ \\
\hline
\end{tabular}

Table A2. Synthesis of interventions retrieved from studies.

\begin{tabular}{|c|c|}
\hline Type of Intervention & Author, Year [49-82] \\
\hline Event history calendar & (Martyn et al., 2012) \\
\hline Group discussion & (Beserra et al., 2008; Fonseca et al., 2010) \\
\hline $\begin{array}{l}\text { Interventions delivered } \\
\text { through School-Based } \\
\text { Health Centers }\end{array}$ & (Bersamin et al., 2018; Denny et al., 2012) \\
\hline Peer education & $\begin{array}{l}\text { (Hatami et al., 2015; Okanlawon and Asuzu, 2013; Stephenson } \\
\text { et al., 2008, 2004) }\end{array}$ \\
\hline Online intervention & $\begin{array}{l}\text { (Aragão et al., 2018; Castillo-Arcos et al., 2016; Enah et al., 2015; } \\
\text { Souza et al., 2017; Valli and Cogo, 2013) }\end{array}$ \\
\hline Mobile phone intervention & $\begin{array}{l}\text { (Alhassan et al., 2019; Cornelius et al., 2019, 2012; French et al., } \\
\text { 2016; Hickman and Schaar, 2018; Rokicki et al., 2017) [49] } \\
\text { (Aventin et al., 2015; Barnes et al., 2004; Beserra et al., 2017; }\end{array}$ \\
\hline Combined interventions & $\begin{array}{l}\text { Gallegos et al., 2008; Hirvonen et al., 2021; Madeni et al., 2011; } \\
\text { Oliveira et al., 2016) }\end{array}$ \\
\hline Workshops & $\begin{array}{l}\text { (Amaral and Fonseca, 2006; Beserra et al., 2006; Camargo and } \\
\text { Ferrari, 2009; Carvalho et al., 2005; Freitas and Dias, 2010; Gubert } \\
\text { et al., 2009; Levandowski and Schmidt, 2010; Santos et al., 2017; } \\
\text { Soares et al., 2008) [50] }\end{array}$ \\
\hline Sex education sessions & $\begin{array}{l}\text { (Dunn et al., 1998; Elliott et al., 2013; Golbasi and Taskin, 2009; } \\
\text { Grandahl et al., 2016; Lieberman et al., 2000; Moodi et al., 2013; } \\
\text { Rani et al., 2016; Serowoky et al., 2015; Walker et al., 2006; Yakubu } \\
\text { et al., 2019) }\end{array}$ \\
\hline $\begin{array}{l}\text { Multiple interventions } \\
\text { program }\end{array}$ & $\begin{array}{l}\text { (Henderson et al., 2007; Jemmott III et al., 1998; Jemmott et al., } \\
\text { 2015; Lonczak et al., 2002; Richards et al., 2019; Siegel et al., 1998; } \\
\text { Tucker et al., 2007; Villarruel et al., 2010, 2006; Wight et al., 2002) }\end{array}$ \\
\hline
\end{tabular}


Table A3. Critical appraisal of studies included in the scoping review.

\begin{tabular}{|c|c|c|c|c|c|c|c|c|c|c|}
\hline Study & $\begin{array}{l}\text { Abstract and } \\
\text { Title }\end{array}$ & $\begin{array}{l}\text { Introduction } \\
\text { and Aims }\end{array}$ & $\begin{array}{l}\text { Method and } \\
\text { Data }\end{array}$ & Sampling & $\begin{array}{c}\text { Data } \\
\text { Analysis }\end{array}$ & $\begin{array}{l}\text { Ethics and } \\
\text { Bias }\end{array}$ & Results & $\begin{array}{l}\text { Transferability or } \\
\text { Generalizability }\end{array}$ & $\begin{array}{c}\text { Implications } \\
\text { and Usefulness }\end{array}$ & TOTAL \\
\hline [58] & 4 & 3 & 4 & 4 & 4 & 4 & 4 & 4 & 4 & 35 \\
\hline [59] & 4 & 4 & 4 & 4 & 4 & 3 & 4 & 4 & 4 & 35 \\
\hline [49] & 4 & 3 & 4 & 4 & 4 & 3 & 4 & 4 & 4 & 34 \\
\hline [47] & 4 & 4 & 4 & 4 & 4 & 3 & 4 & 4 & 3 & 34 \\
\hline [74] & 4 & 3 & 4 & 4 & 4 & 3 & 4 & 4 & 4 & 34 \\
\hline [43] & 4 & 3 & 4 & 4 & 4 & 3 & 4 & 4 & 4 & 34 \\
\hline [23] & 4 & 4 & 3 & 4 & 4 & 2 & 4 & 4 & 4 & 33 \\
\hline [27] & 4 & 3 & 4 & 4 & 4 & 2 & 4 & 4 & 4 & 33 \\
\hline [45] & 4 & 3 & 4 & 4 & 4 & 2 & 4 & 4 & 4 & 33 \\
\hline [70] & 4 & 3 & 4 & 4 & 4 & 3 & 4 & 4 & 3 & 33 \\
\hline [80] & 4 & 3 & 4 & 4 & 4 & 3 & 4 & 4 & 3 & 33 \\
\hline [33] & 4 & 4 & 4 & 4 & 4 & 1 & 4 & 4 & 4 & 33 \\
\hline [82] & 4 & 3 & 4 & 4 & 4 & 3 & 4 & 4 & 3 & 33 \\
\hline [64] & 4 & 4 & 4 & 3 & 3 & 3 & 4 & 3 & 4 & 32 \\
\hline [65] & 4 & 4 & 4 & 4 & 4 & 3 & 4 & 3 & 2 & 32 \\
\hline [72] & 4 & 4 & 4 & 3 & 4 & 3 & 4 & 3 & 3 & 32 \\
\hline [77] & 4 & 4 & 3 & 3 & 4 & 3 & 4 & 3 & 4 & 32 \\
\hline [54] & 4 & 3 & 4 & 3 & 4 & 3 & 4 & 3 & 3 & 31 \\
\hline [57] & 4 & 3 & 4 & 3 & 4 & 3 & 4 & 3 & 3 & 31 \\
\hline [46] & 4 & 3 & 4 & 3 & 4 & 1 & 4 & 4 & 4 & 31 \\
\hline [34] & 4 & 4 & 4 & 3 & 4 & 1 & 4 & 3 & 4 & 31 \\
\hline [79] & 4 & 3 & 4 & 3 & 4 & 3 & 4 & 3 & 3 & 31 \\
\hline [21] & 4 & 3 & 4 & 3 & 4 & 3 & 3 & 4 & 3 & 31 \\
\hline [35] & 4 & 3 & 4 & 3 & 4 & 3 & 4 & 3 & 3 & 31 \\
\hline [81] & 4 & 2 & 3 & 4 & 4 & 2 & 4 & 4 & 4 & 31 \\
\hline [61] & 4 & 3 & 3 & 3 & 4 & 2 & 4 & 3 & 4 & 30 \\
\hline [68] & 4 & 3 & 4 & 3 & 4 & 3 & 4 & 3 & 2 & 30 \\
\hline [69] & 3 & 3 & 4 & 3 & 4 & 3 & 4 & 3 & 3 & 30 \\
\hline [25] & 4 & 3 & 4 & 3 & 4 & 2 & 4 & 3 & 3 & 30 \\
\hline [30] & 3 & 3 & 4 & 2 & 4 & 3 & 4 & 3 & 4 & 30 \\
\hline [32] & 4 & 3 & 3 & 3 & 4 & 2 & 4 & 3 & 4 & 30 \\
\hline
\end{tabular}


Table A3. Cont.

\begin{tabular}{|c|c|c|c|c|c|c|c|c|c|c|}
\hline Study & $\begin{array}{c}\text { Abstract and } \\
\text { Title }\end{array}$ & $\begin{array}{l}\text { Introduction } \\
\text { and Aims }\end{array}$ & $\begin{array}{l}\text { Method and } \\
\text { Data }\end{array}$ & Sampling & $\begin{array}{c}\text { Data } \\
\text { Analysis }\end{array}$ & $\begin{array}{l}\text { Ethics and } \\
\text { Bias }\end{array}$ & Results & $\begin{array}{l}\text { Transferability or } \\
\text { Generalizability }\end{array}$ & $\begin{array}{l}\text { Implications } \\
\text { and Usefulness }\end{array}$ & TOTAL \\
\hline [29] & 4 & 3 & 4 & 2 & 4 & 3 & 4 & 2 & 3 & 29 \\
\hline [22] & 3 & 3 & 4 & 2 & 4 & 3 & 4 & 3 & 3 & 29 \\
\hline [56] & 4 & 3 & 3 & 3 & 4 & 3 & 3 & 3 & 3 & 29 \\
\hline [36] & 4 & 2 & 3 & 3 & 4 & 3 & 4 & 3 & 3 & 29 \\
\hline [26] & 4 & 3 & 4 & 3 & 4 & 3 & 4 & 3 & 4 & 28 \\
\hline [75] & 4 & 3 & 4 & 2 & 3 & 3 & 3 & 3 & 3 & 28 \\
\hline [53] & 4 & 2 & 3 & 2 & 3 & 3 & 4 & 2 & 4 & 27 \\
\hline [38] & 4 & 4 & 3 & 2 & 3 & 3 & 3 & 2 & 3 & 27 \\
\hline [20] & 3 & 3 & 4 & 3 & 3 & 2 & 3 & 3 & 2 & 26 \\
\hline [76] & 3 & 3 & 3 & 3 & 4 & 2 & 4 & 2 & 2 & 26 \\
\hline [55] & 3 & 3 & 3 & 3 & 3 & 2 & 3 & 3 & 2 & 25 \\
\hline [62] & 4 & 3 & 3 & 2 & 3 & 2 & 3 & 3 & 2 & 25 \\
\hline [73] & 3 & 3 & 3 & 3 & 3 & 1 & 3 & 3 & 3 & 25 \\
\hline [28] & 4 & 3 & 2 & 2 & 3 & 2 & 4 & 2 & 3 & 25 \\
\hline [63] & 3 & 3 & 3 & 2 & 3 & 3 & 3 & 2 & 2 & 24 \\
\hline [67] & 3 & 2 & 3 & 2 & 4 & 2 & 4 & 2 & 2 & 24 \\
\hline [52] & 3 & 3 & 3 & 2 & 2 & 2 & 3 & 2 & 3 & 23 \\
\hline [60] & 3 & 3 & 2 & 3 & 2 & 1 & 4 & 3 & 2 & 23 \\
\hline [71] & 2 & 3 & 3 & 2 & 2 & 2 & 3 & 2 & 2 & 21 \\
\hline [78] & 3 & 3 & 1 & 2 & 2 & 1 & 2 & 2 & 2 & 18 \\
\hline
\end{tabular}

4 = Good, 3 = Fair, 2 = Poor, 1 = Very poor. 
Table A4. Study characteristics.

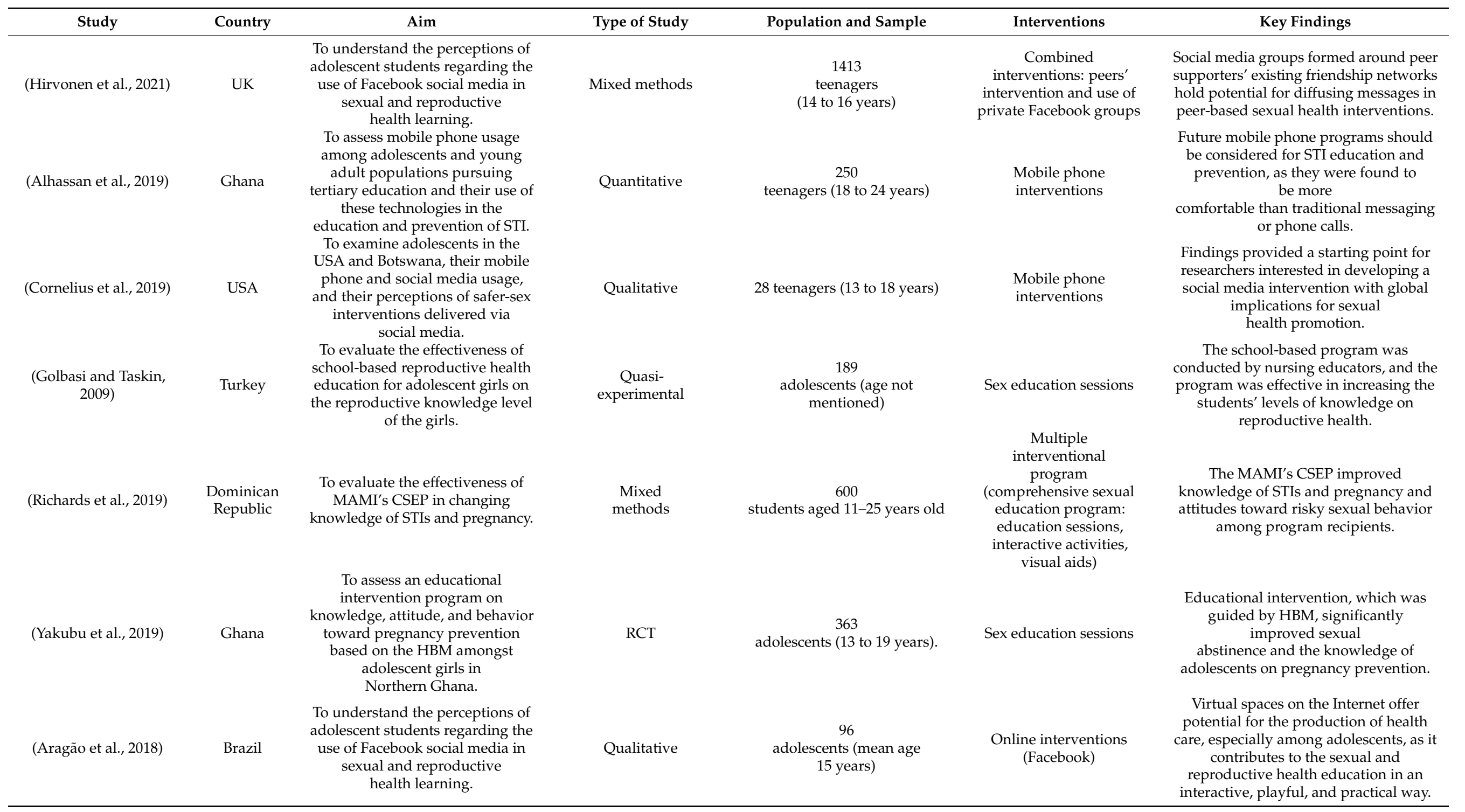


Table A4. Cont.

\begin{tabular}{|c|c|c|c|c|c|c|}
\hline Study & Country & Aim & Type of Study & Population and Sample & Interventions & Key Findings \\
\hline (Bersamin et al., 2018) & USA & $\begin{array}{l}\text { To investigate the associations } \\
\text { between SBHCs and sexual } \\
\text { behavior and contraceptive } \\
\text { use among 11th graders. }\end{array}$ & Quantitative & $\begin{array}{l}11840 \\
\text { adolescents (average age 16.6) }\end{array}$ & $\begin{array}{c}\text { Interventions } \\
\text { delivered through SBHCs }\end{array}$ & $\begin{array}{l}\text { Exposure to SBHCs in general, and } \\
\text { availability of specific reproductive } \\
\text { health services, may be an effective } \\
\text { strategy to support healthy sexual } \\
\text { behaviors among youth. }\end{array}$ \\
\hline $\begin{array}{l}\text { (Hickman and Schaar, } \\
\text { 2018) }\end{array}$ & USA & $\begin{array}{l}\text { To develop and evaluate } \\
\text { adolescent satisfaction with a } \\
\text { text-messaging educational } \\
\text { intervention to promote healthy } \\
\text { behaviors, reduce the incidence of } \\
\text { unhealthy behaviors, and prevent } \\
\text { high-risk behaviors. }\end{array}$ & Mixed methods & $\begin{array}{c}202 \\
\text { adolescents (14 to } 18 \text { years) }\end{array}$ & $\begin{array}{l}\text { Mobile phone } \\
\text { interventions }\end{array}$ & $\begin{array}{l}\text { Text messaging is a good way to educate } \\
\text { adolescents and promote healthy habits, } \\
\text { as it shows a high rate of intended } \\
\text { behavioral change by adolescents. }\end{array}$ \\
\hline (Beserra et al., 2017) & Brazil & $\begin{array}{l}\text { To analyze the perception of } \\
\text { adolescents about the life activity } \\
\text { "express sexuality". }\end{array}$ & Qualitative & 25 teenagers ( 15 to 18 years) & $\begin{array}{l}\text { Combined } \\
\text { interventions: video } \\
\text { projection followed by } \\
\text { discussion and } \\
\text { clarification of doubts }\end{array}$ & $\begin{array}{l}\text { The use of videos followed by discussion } \\
\text { is a valid and useful strategy to help } \\
\text { adolescents in expressing their sexuality. }\end{array}$ \\
\hline (Rokicki et al., 2017) & Ghana & $\begin{array}{l}\text { To evaluate whether } \\
\text { text-messaging programs can } \\
\text { improve reproductive health } \\
\text { among adolescent girls in low- } \\
\text { and middle-income countries. }\end{array}$ & RCT & $\begin{array}{c}756 \\
\text { adolescents (14 to } 24 \text { years) }\end{array}$ & $\begin{array}{l}\text { Mobile phone } \\
\text { interventions }\end{array}$ & $\begin{array}{l}\text { Text-messaging programs can lead to } \\
\text { large improvements in reproductive } \\
\text { health knowledge, and have the } \\
\text { potential to lower pregnancy risk for } \\
\text { sexually active } \\
\text { adolescent girls. }\end{array}$ \\
\hline (Santos et al., 2017) & Brazil & $\begin{array}{l}\text { To report the experience of } \\
\text { conducting a workshop with } \\
\text { teenagers about STIs. }\end{array}$ & Qualitative & $\begin{array}{c}34 \text { adolescents (average age, } \\
18 \text { years old) }\end{array}$ & Workshops & $\begin{array}{l}\text { Group educational experiences provide } \\
\text { adolescents with the opportunity to } \\
\text { build shared knowledge, and } \\
\text { professionals learn about adolescents' } \\
\text { doubts, and therefore plan new health } \\
\text { education meetings. }\end{array}$ \\
\hline (Souza et al., 2017) & Brazil & $\begin{array}{l}\text { To describe the online game and } \\
\text { reflect on its theoretical- } \\
\text { methodological basis. }\end{array}$ & Qualitative & $\begin{array}{l}60 \\
\text { adolescents aged 15-18 years }\end{array}$ & $\begin{array}{l}\text { Online game } \\
\text { (Straight Talk) }\end{array}$ & $\begin{array}{l}\text { Conceived as a pedagogic device, the } \\
\text { online game has the capacity to } \\
\text { implicate the } \\
\text { adolescent in problem-based situations } \\
\text { and allows the invention of other forms } \\
\text { to deal with sexuality without the } \\
\text { demand of } \\
\text { support from a teacher. }\end{array}$ \\
\hline $\begin{array}{l}\text { (Castillo-Arcos et al., } \\
\text { 2016) }\end{array}$ & Mexico & $\begin{array}{l}\text { To evaluate the effect of an } \\
\text { internet-based intervention } \\
\text { to reduce sexual risk behaviors } \\
\text { and increase resilience to sexual } \\
\text { risk behaviors among } \\
\text { Mexican adolescents. }\end{array}$ & $\begin{array}{c}\text { Quasi- } \\
\text { experimental }\end{array}$ & $\begin{array}{c}193 \\
\text { adolescents (14 to } 17 \text { years) }\end{array}$ & $\begin{array}{l}\text { Online interventions (sex } \\
\text { education sessions) }\end{array}$ & $\begin{array}{l}\text { The intervention improved self-reported } \\
\text { resilience to risky sexual behaviors, } \\
\text { though not with a reduction in } \\
\text { those behaviors. }\end{array}$ \\
\hline
\end{tabular}


Table A4. Cont.

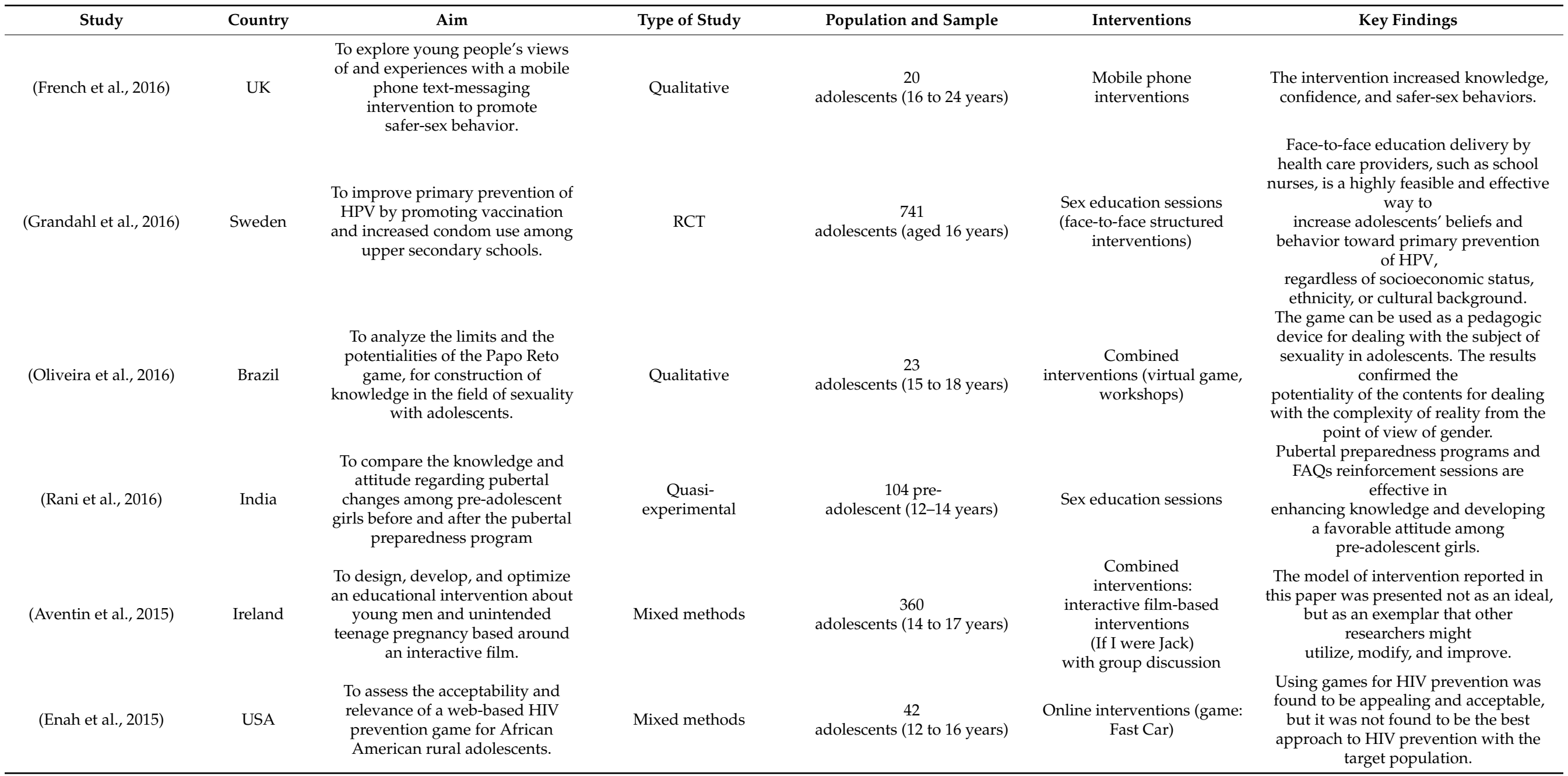


Table A4. Cont.

\begin{tabular}{|c|c|c|c|c|c|c|}
\hline Study & Country & Aim & Type of Study & Population and Sample & Interventions & Key Findings \\
\hline (Hatami et al., 2015) & Iran & $\begin{array}{l}\text { To evaluate the effect of } \\
\text { organizing interactions using peer } \\
\text { education in schools on the } \\
\text { knowledge and attitude toward } \\
\text { sexual health. }\end{array}$ & Quantitative & $\begin{array}{c}282 \\
\text { teenagers (14 to } 18 \text { years) }\end{array}$ & Peer education & $\begin{array}{l}\text { The use of peer education in schools } \\
\text { informally could enhance the } \\
\text { knowledge and approach toward } \\
\text { aspects of physical health, sexual } \\
\text { behaviors, and social and mental } \\
\text { changes among female adolescents. }\end{array}$ \\
\hline (Jemmott et al., 2015) & $\begin{array}{l}2015 \\
\text { South Africa }\end{array}$ & $\begin{array}{l}\text { To test the effect of an HIV/STI } \\
\text { risk-reduction intervention. }\end{array}$ & RCT & $\begin{array}{l}1057 \\
\text { adolescents 9-18 years old }\end{array}$ & Sex education sessions & $\begin{array}{l}\text { The HIV/STI risk-reduction intervention } \\
\text { reduced unprotected intercourse and } \\
\text { caused positive changes on theoretical } \\
\text { constructs. } \\
\text { Theory-based behavioral interventions } \\
\text { with early adolescents can have } \\
\text { long-lived effects in the context of a } \\
\text { generalized severe HIV epidemic. }\end{array}$ \\
\hline (Serowoky et al., 2015) & USA & $\begin{array}{l}\text { To plan, implement, } \\
\text { and evaluate a sustainable model } \\
\text { of sexual health group } \\
\text { programming (Cuídate) in a high } \\
\text { school with a large Latino student } \\
\text { population. }\end{array}$ & $\begin{array}{c}\text { Quasi- } \\
\text { experimental }\end{array}$ & $\begin{array}{c}24 \\
\text { adolescents (13 to } 18 \text { years) }\end{array}$ & $\begin{array}{c}\text { Multiple } \\
\text { interventional } \\
\text { program (Cuídate) }\end{array}$ & $\begin{array}{l}\text { The intervention showed significant } \\
\text { increases in STI or HIV knowledge, } \\
\text { self-efficacy, and intention to use } \\
\text { condoms. It can be sustained in a } \\
\text { school-based health center with results } \\
\text { of efficacy. }\end{array}$ \\
\hline (Elliott et al., 2013) & UK & $\begin{array}{l}\text { To assess the effectiveness of the } \\
\text { Scottish government's National } \\
\text { Sexual Health Demonstration } \\
\text { Project (HR2). }\end{array}$ & $\begin{array}{c}\text { Quasi- } \\
\text { experimental }\end{array}$ & 5283 pupils aged $15-16$ years & Sex education sessions & $\begin{array}{l}\text { Combining sex education and sexual } \\
\text { health services has a limited impact } \\
\text { on young people's sexual health. }\end{array}$ \\
\hline (Moodi et al., 2013) & Iran & $\begin{array}{l}\text { To evaluate the effect of an } \\
\text { educational program for puberty } \\
\text { health on improving intermediate } \\
\text { and high school female students' } \\
\text { knowledge in Birjand, Iran. }\end{array}$ & $\begin{array}{c}\text { Quasi- } \\
\text { experimental }\end{array}$ & $\begin{array}{l}302 \text { female students (mean } \\
\text { age 12.9) }\end{array}$ & Sex education sessions & $\begin{array}{l}\text { Performing educational } \\
\text { programs during } \\
\text { puberty has a crucial role in young girls' } \\
\text { knowledge increase. }\end{array}$ \\
\hline $\begin{array}{l}\text { (Okanlawon and } \\
\text { Asuzu, 2013) }\end{array}$ & Nigeria & $\begin{array}{l}\text { To involve adolescents in } \\
\text { school-based health-promotion } \\
\text { activities that would improve } \\
\text { their perception of risk in sexual } \\
\text { behavior. }\end{array}$ & $\begin{array}{c}\text { Quasi- } \\
\text { experimental }\end{array}$ & $\begin{array}{c}519 \\
\text { adolescents }\end{array}$ & Peer education & $\begin{array}{l}\text { Adolescents' active participation in } \\
\text { health-promotion activities should be } \\
\text { encouraged, as it improves the } \\
\text { perception of risk in } \\
\text { sexual behavior among adolescents. } \\
\text { The blog is a virtual interaction tool }\end{array}$ \\
\hline (Valli and Cogo, 2013) & Brazil & $\begin{array}{l}\text { To analyze the structure of school } \\
\text { blogs on sexuality and their } \\
\text { utilization by adolescents. }\end{array}$ & Quantitative & $\begin{array}{l}11 \text { blogs about } \\
\text { sexuality }\end{array}$ & Online interventions (blog) & $\begin{array}{c}\text { common among adolescents that allows } \\
\text { the adolescent to establish relationships } \\
\text { with other teens interested in the topic, } \\
\text { decreasing feelings of doubt, isolation, } \\
\text { and shyness. }\end{array}$ \\
\hline
\end{tabular}


Table A4. Cont.

\begin{tabular}{|c|c|c|c|c|c|c|}
\hline Study & Country & Aim & Type of Study & Population and Sample & Interventions & Key Findings \\
\hline (Cornelius et al., 2012) & USA & $\begin{array}{l}\text { To understand adolescents' } \\
\text { perceptions of mobile cell phone } \\
\text { text-messaging-enhanced and } \\
\text { mobile cell phone-based HIV- } \\
\text { prevention interventions. }\end{array}$ & Qualitative & 11 teenagers ( 13 to 18 years) & $\begin{array}{l}\text { Mobile phone } \\
\text { interventions }\end{array}$ & $\begin{array}{l}\text { The messages increased participants' } \\
\text { HIV awareness and knowledge. }\end{array}$ \\
\hline (Denny et al., 2012) & New Zealand & $\begin{array}{l}\text { To determine the association } \\
\text { between availability and quality } \\
\text { of school health services and } \\
\text { reproductive health outcomes } \\
\text { among sexually active students. }\end{array}$ & Quantitative & $\begin{array}{c}2745 \\
\text { adolescents (13 to } 17 \text { years) }\end{array}$ & $\begin{array}{l}\text { Interventions } \\
\text { delivered through SBHCs }\end{array}$ & $\begin{array}{l}\text { Health services may be able to lower the } \\
\text { incidence of pregnancy by providing } \\
\text { access to comprehensive health services, } \\
\text { including contraceptive care that is } \\
\text { easily available and appropriate for the } \\
\text { student population. }\end{array}$ \\
\hline (Martyn et al., 2012) & USA & $\begin{array}{l}\text { To explore the effects of an event } \\
\text { history calendar approach on } \\
\text { adolescent sexual risk } \\
\text { communication and } \\
\text { sexual activity. }\end{array}$ & Mixed methods & $\begin{array}{c}30 \\
\text { adolescents (15 to } 19 \text { years) }\end{array}$ & Event history calendar & $\begin{array}{l}\text { School nurses could use the event } \\
\text { history calendar approach to improve } \\
\text { adolescent communication on sexual } \\
\text { risks and tailoring of interventions. }\end{array}$ \\
\hline (Madeni et al., 2011) & Tanzania & $\begin{array}{l}\text { To evaluate a reproductive health } \\
\text { awareness program for the } \\
\text { improvement of reproductive } \\
\text { health for unmarried adolescent } \\
\text { girls and boys in urban Tanzania. }\end{array}$ & $\begin{array}{c}\text { Quasi- } \\
\text { experimental }\end{array}$ & $\begin{array}{c}305 \\
\text { adolescents (11 to } 16 \text { years) }\end{array}$ & $\begin{array}{l}\text { Combined } \\
\text { interventions (sex } \\
\text { education sessions and } \\
\text { group discussions) }\end{array}$ & $\begin{array}{l}\text { The reproductive health program } \\
\text { improved the students' knowledge and } \\
\text { behavior about sexuality and decision } \\
\text { making after the program for both girls } \\
\text { and boys. Their attitudes were not likely } \\
\text { to change based on the educational } \\
\text { intervention. }\end{array}$ \\
\hline (Fonseca et al., 2010) & Brazil & $\begin{array}{l}\text { To find the perception of } \\
\text { adolescents on the sexual } \\
\text { orientation actions in a public } \\
\text { school and to identify the actions' } \\
\text { fragilities and potentials. }\end{array}$ & Qualitative & $\begin{array}{c}15 \\
\text { adolescents (15 to } 17 \text { years) }\end{array}$ & Group discussions & $\begin{array}{c}\text { Participative methodology promotes a } \\
\text { welcoming and productive work climate } \\
\text { and provides larger involvement and } \\
\text { learning. }\end{array}$ \\
\hline (Freitas and Dias, 2010) & Brazil & $\begin{array}{l}\text { To understand teenagers' } \\
\text { perceptions about the } \\
\text { development of their sexuality. }\end{array}$ & Qualitative & 12 teenagers (11 to 19 years) & Workshops & $\begin{array}{c}\text { Teenagers' perceptions about their } \\
\text { sexuality emerged from the debates and } \\
\text { shared knowledge during } \\
\text { the workshops. }\end{array}$ \\
\hline $\begin{array}{l}\text { (Levandowski and } \\
\text { Schmidt, 2010) }\end{array}$ & Brazil & $\begin{array}{l}\text { To enable the exchange of } \\
\text { experiences and reflection about } \\
\text { sexuality-related actions } \\
\text { and choices. }\end{array}$ & Qualitative & $\begin{array}{c}270 \\
\text { adolescents (12 to } 15 \text { years) }\end{array}$ & Workshops & $\begin{array}{l}\text { The intervention reduced psychosocial } \\
\text { risk factors, providing a } \\
\text { healthy development. }\end{array}$ \\
\hline
\end{tabular}


Table A4. Cont.

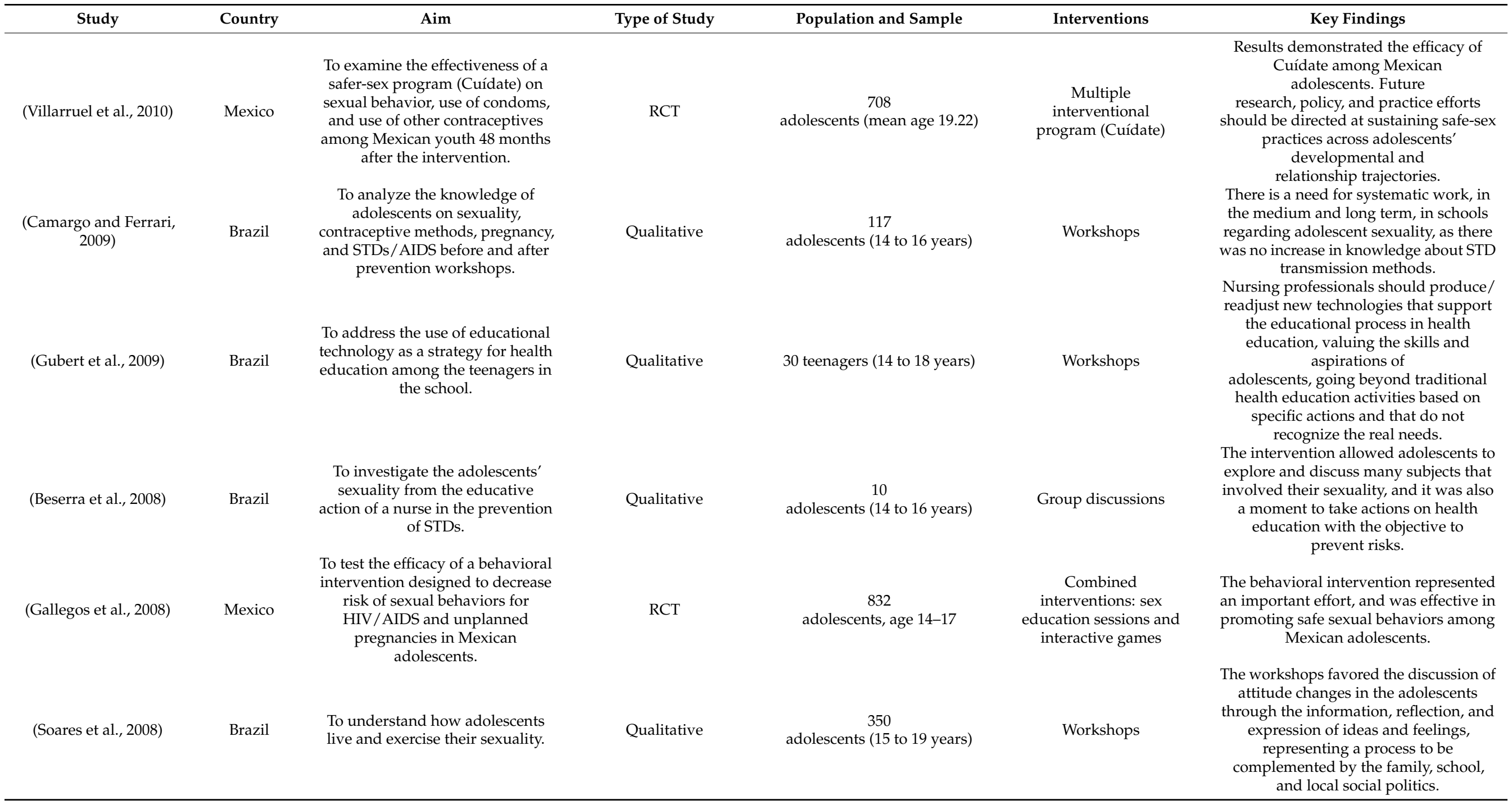


Table A4. Cont.

Study Country

(Henderson et al., 2007)

Scotland

(Tucker et al., 2007)

2006

UK-Lothian 2006)

Brazil

To understand adolescents' socia representations on sexual initiation concerning gender.

To describe an experience to

(Beserra et al., 2006) Brazil promote health and prevent STDs

$$
\text { among teenagers. }
$$
intervention to reduce sexual risk behavior among Latino

$$
\text { adolescents. }
$$

To assess effects on condom use and other sexual behavior of an

(Walker et al., 2006)

Mexico

HIV prevention program at schoo

hat promotes the use of condoms
To test the efficacy of a prevention

Type of Study

Population and Sample

4196 female (mean age 20)

4381

Quasi-

experimental

pupils

(average age 14.6 years)

Multiple intervention

program (SHARE)

Multiple intervention

program (SHARE)

with and without

emergency contraception
Qualitative

RCT

Qualitative

adolescents (11 to 16 years)

28

adolescents (13 to 16 years)

$$
553
$$

adolescents, aged 13 to 18

$$
\text { years }
$$

First-year high school student

$(n=10954)(16-17$ years $)$
Multiple interventional

Sex education session program (Cuídate)

\section{Key Findings}

Enhanced teacher-led school sex education (SHARE) improved knowledge and

reduced regret, but did not reduce conceptions or terminations compared with conventional sex education.

The findings demonstrated limited impact on sexual health behavior outcomes and raised questions about the likely and achievable sexual health gains for teenagers from

school-based interventions.

The strategy allowed the understanding of the social representations of teenager about sexual initiation, being of great importance for planning the work developed with

teenagers, supporting debates and reflections on the experience of healthy and responsible sexuality by young people.

The strategy was effective at promoting teenagers' adoption of preventative measures.

Results provided evidence for efficacy for HIV prevention in decreasing sexual activity and increasing condom use among Latino adolescents.

A rigorously designed, implemented, and evaluated HIV education course based in public high schools did not reduce risk

behavior, so such courses need to be redesigned and evaluated. 
Table A4. Cont.

\begin{tabular}{|c|c|c|c|c|c|c|}
\hline Study & Country & Aim & Type of Study & Population and Sample & Interventions & Key Findings \\
\hline (Carvalho et al., 2005) & Brazil & $\begin{array}{l}\text { To determine how the } \\
\text { intervention in sexual } \\
\text { guidance was } \\
\text { experienced by adolescents. }\end{array}$ & Qualitative & $\begin{array}{c}13 \\
\text { adolescents (13 to } 15 \text { years) }\end{array}$ & Workshops & $\begin{array}{l}\text { The analysis demonstrated a } \\
\text { reconstruction / redefinition of meaning } \\
\text { for the ideas } \\
\text { related to sexuality, to gender, and to the } \\
\text { wider social context. }\end{array}$ \\
\hline (Barnes et al., 2004) & Australia & $\begin{array}{l}\text { To evaluate the impact of changes } \\
\text { in the health system and services } \\
\text { on the roles and responsibilities of } \\
\text { child health nurses and to identify } \\
\text { professional development needs. }\end{array}$ & Qualitative & 10 nurses & $\begin{array}{l}\text { Combined } \\
\text { interventions: health } \\
\text { education and health } \\
\text { information displays. }\end{array}$ & $\begin{array}{l}\text { The school-based youth health nurse } \\
\text { program provides nurses with a new, } \\
\text { challenging, autonomous role within the } \\
\text { school environment, and the } \\
\text { opportunity to expand their role to } \\
\text { incorporate all aspects of the } \\
\text { health-promoting schools' } \\
\text { framework. }\end{array}$ \\
\hline (Stephenson et al., 2004) & UK & $\begin{array}{l}\text { To examine the effectiveness of } \\
\text { one form of peer-led } \\
\text { sex education. }\end{array}$ & $\mathrm{RCT}$ & $\begin{array}{c}8000 \\
\text { students (13 to } 14 \text { years) }\end{array}$ & Peer education & $\begin{array}{l}\text { Peer-led sex education was effective in } \\
\text { some ways, but broader strategies are } \\
\text { needed to improve young people's } \\
\text { sexual health. The role of single-sex } \\
\text { sessions should be further investigated. } \\
\text { A theory-based social development }\end{array}$ \\
\hline (Lonczak et al., 2002) & USA & $\begin{array}{l}\text { To examine the long-term effects } \\
\text { of the full SSDP intervention on } \\
\text { sexual behavior and associated } \\
\text { outcomes assessed at age } 21 \text { years. }\end{array}$ & $\begin{array}{l}\text { Non- } \\
\text { randomized controlled } \\
\text { trial }\end{array}$ & $\begin{array}{l}349 \text { former fifth-grade } \\
\text { students (aged } 21 \text { years) }\end{array}$ & $\begin{array}{c}\text { Multiple } \\
\text { interventional } \\
\text { program (SSDP) }\end{array}$ & $\begin{array}{l}\text { program that promotes academic } \\
\text { success, social competence, and bonding } \\
\text { to school during the elementary grades } \\
\text { can prevent risky sexual practices and } \\
\text { adverse health consequences in } \\
\text { early adulthood. }\end{array}$ \\
\hline (Wight et al., 2002) & Scotland & $\begin{array}{l}\text { To determine whether a } \\
\text { theoretically based sex education } \\
\text { program for adolescents (SHARE) } \\
\text { delivered by teachers } \\
\text { reduced unsafe sexual intercourse } \\
\text { compared with current practice. }\end{array}$ & RCT & 8430 pupils aged $13-15$ years & $\begin{array}{l}\text { Multiple intervention } \\
\text { program (SHARE) }\end{array}$ & $\begin{array}{l}\text { Compared with conventional sex } \\
\text { education, this specially designed } \\
\text { intervention did not reduce sexual } \\
\text { risk-taking in adolescents. }\end{array}$ \\
\hline (Lieberman et al., 2000) & USA & $\begin{array}{l}\text { To assess the impact of an } \\
\text { abstinence-based model for } \\
\text { sexual education. }\end{array}$ & Quantitative & $\begin{array}{c}312 \\
\text { students (mean age 12.9) }\end{array}$ & $\begin{array}{l}\text { Multiple intervention } \\
\text { program } \\
\text { (IMPPACT) }\end{array}$ & $\begin{array}{l}\text { A small-group abstinence-based } \\
\text { intervention can have some impact on } \\
\text { adolescents' attitudes and relationships } \\
\text { (particularly with their parents). }\end{array}$ \\
\hline (Dunn et al., 1998) & Canada & $\begin{array}{l}\text { To evaluate a school-based HIV } \\
\text { prevention intervention in } \\
\text { adolescents. }\end{array}$ & $\begin{array}{c}\text { Quasi- } \\
\text { experimental }\end{array}$ & $\begin{array}{c}160 \\
\text { adolescents (14 to } 15 \text { years) }\end{array}$ & Sex education sessions & $\begin{array}{l}\text { School-based interventions can improve } \\
\text { adolescents' short-term HIV / AIDS } \\
\text { prevention knowledge, attitudes, } \\
\text { self-efficacy, and behavioral intentions. }\end{array}$ \\
\hline
\end{tabular}


Table A4. Cont.

\begin{tabular}{|c|c|c|c|c|c|c|}
\hline Study & Country & Aim & Type of Study & Population and Sample & Interventions & Key Findings \\
\hline (Jemmott III et al., 1998) & USA & $\begin{array}{l}\text { To evaluate the effects of } \\
\text { abstinence and safer-sex HIV } \\
\text { risk-reduction interventions on } \\
\text { young inner-city African } \\
\text { American adolescent's HIV } \\
\text { sexual risk } \\
\text { behaviors when implemented by } \\
\text { adult facilitators as compared } \\
\text { with peer cofacilitators. }\end{array}$ & $\mathrm{RCT}$ & $\begin{array}{c}659 \\
\text { adolescents (mean age 11.8) }\end{array}$ & Sex education sessions & $\begin{array}{c}\text { Both abstinence and safer-sex } \\
\text { interventions can reduce HIV sexual risk } \\
\text { behaviors, but safer-sex interventions } \\
\text { may have } \\
\text { longer-lasting effects, and may be } \\
\text { especially effective with } \\
\text { sexually experienced } \\
\text { adolescents. }\end{array}$ \\
\hline (Siegel et al., 1998) & USA & $\begin{array}{l}\text { To determine the short-term effect } \\
\text { of a middle and high school-based } \\
\text { AIDS and sexuality intervention } \\
\text { (RAPP) on knowledge, } \\
\text { self-efficacy, and behavior } \\
\text { intention. }\end{array}$ & $\begin{array}{l}\text { Non- } \\
\text { randomized controlled } \\
\text { trial }\end{array}$ & $\begin{array}{l}\text { Middle and high } \\
\text { school students } \\
\quad(n=3635)\end{array}$ & $\begin{array}{c}\text { Multiple } \\
\text { interventional } \\
\text { program (RAPP): games, } \\
\text { role playing, } \\
\text { take-home exercises }\end{array}$ & $\begin{array}{c}\text { At short-term follow-up, the RAPP } \\
\text { intervention had a powerful effect on } \\
\text { knowledge for all students and a } \\
\text { moderate effect on sexual self-efficacy } \\
\text { and safe } \\
\text { behavior intention, particularly for high } \\
\text { school students. }\end{array}$ \\
\hline (Stephenson et al., 2008) & UK & $\begin{array}{l}\text { To assess the long-term effects of a } \\
\text { peer-led sex education program. }\end{array}$ & $\mathrm{RCT}$ & $\begin{array}{c}9000 \\
\text { students (13-14 years) }\end{array}$ & Peer education & $\begin{array}{l}\text { Compared with conventional school sex } \\
\text { education at age } 13-14 \mathrm{y} \text {, this form of } \\
\text { peer-led sex education was not } \\
\text { associated with a change in teenage } \\
\text { abortions, but may have led to fewer } \\
\text { teenage births, and was popular with } \\
\text { pupils. It merits consideration within } \\
\text { broader teenage-pregnancy- } \\
\text { prevention strategies. }\end{array}$ \\
\hline
\end{tabular}




\section{References}

1. World Health Organization. Implementing the global reprodutive health strategy. Policy Br. World Health Organ. Dept. Reprod. Health Res. 2006, 2, 7.

2. Holland-Hall, C.; Quint, E.H. Sexuality and disability in adolescents. Pediatr. Clin. N. Am. 2017, 64, 435-449. [CrossRef]

3. Sawyer, S.M.; Azzopardi, P.S.; Wickremarathne, D.; Patton, G.C. The age of adolescence. Lancet Child Adolesc. Health 2018, 2, 223-228. [CrossRef]

4. Mullinax, M.; Mathur, S.; Santelli, J. Adolescent Sexual Health and Sexuality Education; Cherry, A.L., Baltag, V., Dillon, M.E., Eds.; Springer International Publishing: Berlin/Heidelberg, Germany, 2017. [CrossRef]

5. Goettsch, S.L. Clarifying basic concepts: Conceptualizing sexuality. J. Sex Res. 1989, 26, 249-255. [CrossRef]

6. Young, I. Health promotion in schools-A historical perspective. Promot. Educ. 2005, 12, 112-117. [CrossRef] [PubMed]

7. Inchley, J.; Currie, D.; Budisavljevic, S.; Torsheim, T.; Jåstad, A.; Cosma, A.; Kelly, C.; Már Arnarsson, Á. Spotlight on Adolescent Health and Well-Being Survey in Europe and Canada International Report Volume 1. Key Findings; HBSC: Glasgow, UK, 2018.

8. Leung, H.; Shek, D.; Leung, E.; Shek, E. Development of contextually-relevant sexuality education: Lessons from a comprehensive review of adolescent sexuality education across cultures. Int. J. Environ. Res. Public Health 2019, 16, 621. [CrossRef] [PubMed]

9. Michielsen, K.; De Meyer, S.; Ivanova, O.; Anderson, R.; Decat, P.; Herbiet, C.; Kabiru, C.W.; Ketting, E.; Lees, J.; Moreau, C.; et al. Reorienting adolescent sexual and reproductive health research: Reflections from an international conference. Reprod. Health 2015, 13, 3. [CrossRef] [PubMed]

10. Shackleton, N.; Jamal, F.; Viner, R.M.; Dickson, K.; Patton, G.; Bonell, C. School-based interventions going beyond health education to promote adolescent health: Systematic review of reviews. J. Adolesc. Health 2016, 58, 382-396. [CrossRef] [PubMed]

11. Mmari, K.; Sabherwal, S. A review of risk and protective factors for adolescent sexual and reproductive health in developing countries: An Update. J. Adolesc. Health 2013, 53, 562-572. [CrossRef] [PubMed]

12. Willgerodt, M.A.; Brock, D.M.; Maughan, E.D. Public school nursing practice in the United States. J. Sch. Nurs. 2018, 34, 232-244. [CrossRef] [PubMed]

13. Leroy, Z.C.; Wallin, R.; Lee, S. The role of school health services in addressing the needs of students with chronic health conditions J. Sch. Nurs. 2017, 33, 64-72. [CrossRef] [PubMed]

14. Santa Maria, D.; Guilamo-Ramos, V.; Jemmott, L.S.; Derouin, A.; Villarruel, A. Nurses on the front lines. AJN Am. J. Nurs. 2017, 117, 42-51. [CrossRef] [PubMed]

15. Tricco, A.C.; Lillie, E.; Zarin, W.; O’Brien, K.K.; Colquhoun, H.; Levac, D.; Moher, D.; Peters, M.D.J.; Horsley, T.; Weeks, L.; et al PRISMA Extension for Scoping Reviews (PRISMA-ScR): Checklist and explanation. Ann. Intern. Med. 2018, 169, 467. [CrossRef]

16. Munn, Z.; Peters, M.D.J.; Stern, C.; Tufanaru, C.; McArthur, A.; Aromataris, E. Systematic review or scoping review? Guidance for authors when choosing between a systematic or scoping review approach. BMC Med. Res. Methodol. 2018, 18, 143. [CrossRef] [PubMed]

17. Peters, M.; Godfrey, C.M.; Mcinerney, P.; Baldini Soares, C.; Khalil, H.; Parker, D. Guidance for the Conduct of JBI Scoping Reviews. In Joana Briggs Institute Reviewer's Manual; Aromataris, E., Munn, Z., Eds.; The Joanna Briggs Institute: Adelaide, Australia, 2017; pp. 141-146.

18. Hawker, S.; Payne, S.; Kerr, C.; Hardey, M.; Powell, J. Appraising the evidence: Reviewing disparate data systematically. Qual. Health Res. 2002, 12, 1284-1299. [CrossRef]

19. World Health Organization. International Classification of Health Interventions. Available online: https://www.who.int/ standards/classifications/international-classification-of-health-interventions (accessed on 7 September 2021).

20. Barnes, M.; Courtney, M.D.; Pratt, J.; Walsh, A.M. School-based youth health nurses: Roles, responsibilities, challenges, and rewards. Public Health Nurs. 2004, 21, 316-322. [CrossRef]

21. Valli, G.P.; Cogo, A.L.P. School blogs about sexuality: An exploratory documentary study. Rev. Gaúcha Enferm. $2013,34,31-37$. [CrossRef]

22. Beserra, E.P.; da Pinheiro, P.N.C.; Barroso, M.G.T. Educative action of nurse in the prevention of sexually transmitted diseases: An investigation with the adolescents. Esc. Anna Nery 2008, 12, 522-528. [CrossRef]

23. Bersamin, M.; Paschall, M.J.; Fisher, D.A. Oregon school-based health centers and sexual and contraceptive behaviors among adolescents. J. Sch. Nurs. 2018, 34, 359-366. [CrossRef] [PubMed]

24. Grandahl, M.; Rosenblad, A.; Stenhammar, C.; Tydén, T.; Westerling, R.; Larsson, M.; Oscarsson, M.; Andrae, B.; Dalianis, T.; Nevéus, T. School-based intervention for the prevention of HPV among adolescents: A cluster randomised controlled study. BMJ Open 2016, 6, e009875. [CrossRef]

25. Hirvonen, M.; Purcell, C.; Elliott, L.; Bailey, J.V.; Simpson, S.A.; McDaid, L.; Moore, L.; Mitchell, K.R. Peer-to-peer sharing of social media messages on sexual health in a school-based intervention: Opportunities and challenges identified in the STASH feasibility trial. J. Med. Internet Res. 2021, 23, e20898. [CrossRef]

26. Martyn, K.K.; Darling-Fisher, C.; Pardee, M.; Ronis, D.L.; Felicetti, I.L.; Saftner, M.A. Improving sexual risk communication with adolescents using event history calendars. J. Sch. Nurs. 2012, 28, 108-115. [CrossRef]

27. Enah, C.; Piper, K.; Moneyham, L. Qualitative evaluation of the relevance and acceptability of a web-based HIV prevention game for rural adolescents. J. Pediatr. Nurs. 2015, 30, 321-328. [CrossRef] [PubMed] 
28. Richards, S.D.; Mendelson, E.; Flynn, G.; Messina, L.; Bushley, D.; Halpern, M.; Amesty, S.; Stonbraker, S. Evaluation of a comprehensive sexuality education program in La Romana, Dominican Republic. Int. J. Adolesc. Med. Health 2019, 1-18. [CrossRef] [PubMed]

29. Aragão, J.M.N.; do Gubert, F.A.; Torres, R.A.M.; da Silva, A.S.R.; Vieira, N.F.C. The use of facebook in health education: Perceptions of adolescent students. Rev. Bras. Enferm. 2018, 71, 265-271. [CrossRef] [PubMed]

30. Soares, S.M.; Amaral, M.A.; Silva, L.B.; Silva, P.A.B. Workshops on sexuality in adolescence: Revealing voices, unveiling views student's of the medium teaching glances. Esc. Anna Nery 2008, 12, 485-491. [CrossRef]

31. Henderson, M.; Wight, D.; Raab, G.M.; Abraham, C.; Parkes, A.; Scott, S.; Hart, G. Impact of a Theoretically Based Sex Education Programme (SHARE) delivered by teachers on NHS registered conceptions and terminations: Final results of cluster randomised trial. BMJ 2007, 334, 133. [CrossRef]

32. Tucker, J.S.; Fitzmaurice, A.E.; Imamura, M.; Penfold, S.; Penney, G.C.; Van Teijlingen, E.; Shucksmith, J.; Philip, K.L. The effect of the national demonstration project healthy respect on teenage sexual health behaviour. Eur. J. Public Health 2007, 17 , 33-41. [CrossRef]

33. Wight, D.; Raab, G.M.; Henderson, M.; Abraham, C.; Buston, K.; Hart, G.; Scott, S. Limits of teacher delivered sex education: Interim behavioural outcomes from randomised trial. BMJ 2002, 324, 1430. [CrossRef]

34. Serowoky, M.L.; George, N.; Yarandi, H. Using the program logic model to evaluate ¡Cuídate!: A sexual health program for latino adolescents in a school-based health center. Worldviews Evid.-Based Nurs. 2015, 12, 297-305. [CrossRef] [PubMed]

35. Villarruel, A.M.; Jemmott, J.B.; Jemmott, L.S. A randomized controlled trial testing an HIV Prevention Intervention for Latino Youth. Arch. Pediatr. Adolesc. Med. 2006, 160, 772. [CrossRef] [PubMed]

36. Villarruel, A.M.; Zhou, Y.; Gallegos, E.C.; Ronis, D.L. Examining long-term effects of cuídate-a sexual risk reduction program in Mexican Youth. Rev. Panam. Salud Pública 2010, 27, 345-351. [CrossRef]

37. Salam, R.A.; Das, J.K.; Lassi, Z.S.; Bhutta, Z.A. Adolescent health interventions: Conclusions, evidence gaps, and research priorities. J. Adolesc. Health 2016, 59, S88-S92. [CrossRef] [PubMed]

38. De Souza, V.; Gazzinelli, M.F.; Soares, A.N.; Fernandes, M.M.; de Oliveira, R.N.G.; da Fonseca, R.M.G.S. The game as strategy for approach to sexuality with adolescents: Theoretical-methodological reflections. Rev. Bras. Enferm. 2017, 70, 376-383. [CrossRef]

39. Giovanelli, A.; Ozer, E.M.; Dahl, R.E. Leveraging technology to improve health in adolescence: A developmental science perspective. J. Adolesc. Health 2020, 67, S7-S13. [CrossRef] [PubMed]

40. L'Engle, K.L.; Mangone, E.R.; Parcesepe, A.M.; Agarwal, S.; Ippoliti, N.B. Mobile phone interventions for adolescent sexual and reproductive health: A systematic review. Pediatrics 2016, 138, e20160884. [CrossRef] [PubMed]

41. McNall, M.A.; Lichty, L.F.; Mavis, B. The impact of school-based health centers on the health outcomes of middle school and high school students. Am. J. Public Health 2010, 100, 1604-1610. [CrossRef]

42. Brewin, D.; Koren, A.; Morgan, B.; Shipley, S.; Hardy, R.L. Behind closed doors. J. Sch. Nurs. 2014, 30, 31-41. [CrossRef]

43. Stephenson, J.; Strange, V.; Allen, E.; Copas, A.; Johnson, A.; Bonell, C.; Babiker, A.; Oakley, A. The Long-Term Effects of a Peer-Led Sex Education Programme (RIPPLE): A cluster randomised trial in schools in England. PLoS Med. 2008, 5, e224. [CrossRef] [PubMed]

44. Denford, S.; Abraham, C.; Campbell, R.; Busse, H. A Comprehensive review of reviews of school-based interventions to improve sexual-health. Health Psychol. Rev. 2017, 11, 33-52. [CrossRef] [PubMed]

45. Jemmott, J.B.; Jemmott, L.S.; O’Leary, A.; Ngwane, Z.; Lewis, D.A.; Bellamy, S.L.; Icard, L.D.; Carty, C.; Heeren, G.A.; Tyler, J.C.; et al. HIV/STI risk-reduction intervention efficacy with South African adolescents over 54 months. Health Psychol. 2015, 34, 610-621. [CrossRef] [PubMed]

46. Lieberman, L.D.; Gray, H.; Wier, M.; Fiorentino, R.; Maloney, P. Long-term outcomes of an abstinence-based, small-group pregnancy prevention program in New York City Schools. Fam. Plann. Perspect. 2000, 32, 237-245. [CrossRef]

47. Lonczak, H.S.; Abbott, R.D.; Hawkins, J.D.; Kosterman, R.; Catalano, R.F. Effects of the seattle social development project on sexual behavior, pregnancy, birth, and sexually transmitted disease outcomes by age 21 Years. Arch. Pediatr. Adolesc. Med. 2002, 156, 438. [CrossRef] [PubMed]

48. Domitrovich, C.E.; Durlak, J.A.; Staley, K.C.; Weissberg, R.P. Social-emotional competence: An essential factor for promoting positive adjustment and reducing risk in school children. Child Dev. 2017, 88, 408-416. [CrossRef] [PubMed]

49. Alhassan, R.K.; Abdul-Fatawu, A.; Adzimah-Yeboah, B.; Nyaledzigbor, W.; Agana, S.; Mwini-Nyaledzigbor, P.P. Determinants of Use of Mobile Phones for Sexually Transmitted Infections (STIs) education and prevention among adolescents and young adult population in Ghana: Implications of public health policy and interventions design. Reprod. Health 2019, 16, 120. [CrossRef]

50. Amaral, M.A.; da Fonseca, R.M.G.S. Between desire and fear: Female adolescents' social representation on sexual initiation. Rev. Esc. Enferm. USP 2006, 40, 469-476. [CrossRef] [PubMed]

51. Aventin, Á.; Lohan, M.; O'Halloran, P.; Henderson, M. Design and development of a film-based intervention about teenage men and unintended pregnancy: Applying the medical research council framework in practice. Eval. Program Plann. 2015, 49, 19-30. [CrossRef]

52. Beserra, E.P.; Sousa, L.B.; Cardoso, V.P.; Alves, M.D.S. Perception of adolescents about the life activity "express sexuality". Rev. Pesqui. Cuid. Fundam. Online 2017, 9, 340-346. [CrossRef]

53. Beserra, E.P.; de Araújo, M.F.M.; Barroso, M.G.T. Health promotion in transmissible diseases-An investigation among teenagers. ACTA Paul. Enferm. 2006, 19, 402-407. [CrossRef] 
54. Camargo, E.Á.I.; Ferrari, R.A.P. Adolescents: Knowledge about sexuality before and after participating in prevention workshops. Cien. Saude Colet. 2009, 14, 937-946. [CrossRef]

55. Carvalho, A.M.; Rodrigues, C.S.; Medrado, K.S. Workshop in human sexuality with adolescents. Estud. Psicol. 2005, 10, 377-384. [CrossRef]

56. Castillo-Arcos, L.D.C.; Benavides-Torres, R.A.; López-Rosales, F.; Onofre-Rodríguez, D.J.; Valdez-Montero, C.; Maas-Góngora, L. The effect of an internet-based intervention designed to reduce HIV / AIDS sexual risk among mexican adolescents. AIDS Care 2016, 28, 191-196. [CrossRef]

57. Cornelius, J.B.; Whitaker-Brown, C.; Neely, T.; Kennedy, A.; Okoro, F. Mobile phone, social media usage, and perceptions of delivering a social media safer sex intervention for adolescents: Results from two countries. Adolesc. Health Med. Ther. 2019, 10, 29-37. [CrossRef]

58. Cornelius, J.B.; St. Lawrence, J.S.; Howard, J.C.; Shah, D.; Poka, A.; McDonald, D.; White, A.C. Adolescents' perceptions of a mobile cell phone text messaging-enhanced intervention and development of a mobile cell phone-based HIV prevention intervention. J. Spec. Pediatr. Nurs. 2012, 17, 61-69. [CrossRef] [PubMed]

59. Denny, S.; Robinson, E.; Lawler, C.; Bagshaw, S.; Farrant, B.; Bell, F.; Dawson, D.; Nicholson, D.; Hart, M.; Fleming, T.; et al. Association between availability and quality of health services in schools and reproductive health outcomes among students: A multilevel observational study. Am. J. Public Health 2012, 102, e14-e20. [CrossRef]

60. Dunn, L.; Ross, B.; Caines, T.; Howorth, P. A School-Based HIV/AIDS prevention education program: Outcomes of peer-led versus community health nurse-led interventions. J. Pract. Nurs. 1998, 42, 49.

61. Elliott, L.; Henderson, M.; Nixon, C.; Wight, D. Has untargeted sexual health promotion for young people reached its limit? A quasi-experimental study. J. Epidemiol. Commun. Health 2013, 67, 398-404. [CrossRef] [PubMed]

62. Da Fonseca, A.D.; Gomes, V.L.D.O.; Teixeira, K.C. Perception of adolescents about an educative action in sexual orientation conducted by nursing academics'. Esc. Anna Nery 2010, 14, 330-337. [CrossRef]

63. De Freitas, K.R.; Dias, S.M.Z. Teenagers' perceptions regarding their sexuality. Texto Context. Enferm. 2010, 19, 351-357. [CrossRef]

64. French, R.S.; McCarthy, O.; Baraitser, P.; Wellings, K.; Bailey, J.V.; Free, C. Young people's views and experiences of a mobile phone texting intervention to promote safer sex behavior. JMIR mHealth uHealth 2016, 4, e26. [CrossRef]

65. Gallegos, E.C.; Villarruel, A.M.; Loveland-Cherry, C.; Ronis, D.L.; Yan Zhou, M. Intervención para reducir riesgo en conductas sexuales de adolescentes: Un ensayo aleatorizado y controlado. Salud Publica Mex. 2008, 50, 59-66. [CrossRef]

66. Golbasi, Z.; Taskin, L. Evaluation of school-based reproductive health education program for adolescent girls. Int. J. Adolesc. Med. Health 2009, 21, 395-404. [CrossRef] [PubMed]

67. Gubert, F.A.; dos Santos, A.C.L.; Aragão, K.A.; Pereira, D.C.R.; Vieira, N.F.C.; Pinheiro, P.N.C. Educational technology in the school context: Strategy for health education in a public school in fortaleza-CE. Rev. Eletronica Enferm. 2009, 11, 165-172.

68. Hatami, M.; Kazemi, A.; Mehrabi, T. Effect of peer education in school on sexual health knowledge and attitude in girl adolescents. J. Educ. Health Promot. 2015, 4, 78. [CrossRef] [PubMed]

69. Hickman, N.E.; Schaar, G. Impact of an educational text message intervention on adolescents' knowledge and high-risk behaviors. Compr. Child. Adolesc. Nurs. 2018, 41, 71-82. [CrossRef] [PubMed]

70. Jemmott, J.B., III; Sweet Jemmott, L.; Fong, G.T. Abstinence and safer sex HIV risk-reduction interventions for African American Adolescents. JAMA 1998, 279, 1529. [CrossRef]

71. Levandowski, D.C.; Schmidt, M.M. Workshop addressing sexuality and dating directed to adolescents. Paid 2010, 20, 431-436. [CrossRef]

72. Madeni, F.; Horiuchi, S.; Iida, M. Evaluation of a reproductive health awareness program for adolescence in urban Tanzania-A quasi-experimental pre-test post-test research. Reprod. Health 2011, 8, 21. [CrossRef] [PubMed]

73. Moodi, M.; Shahnazi, H.; Sharifirad, G.-R.; Zamanipour, N. Evaluating puberty health program effect on knowledge increase among female intermediate and high school students in Birjand, Iran. J. Educ. Health Promot. 2013, 2, 57. [CrossRef] [PubMed]

74. Okanlawon, F.A.; Asuzu, M.C. Secondary school adolescents' perception of risk in sexual behaviour in rural community of Oyo State, Nigeria. J. Community Med. Prim. Health Care 2013, 24, 21-28.

75. De Oliveira, R.N.G.; Gessner, R.; de Souza, V.; da Fonseca, R.M.G.S. Limits and possibilities of an online game for building adolescents' knowledge of sexuality. Cien. Saude Colet. 2016, 21, 2383-2392. [CrossRef]

76. Rani, M.; Sheoran, P.; Kumar, Y.; Singh, N. Evaluating the effectiveness of pubertal preparedness program in terms of knowledge and attitude regarding pubertal changes among pre-adolescent girls. J. Fam. Reprod. Health 2016, 10, $122-128$.

77. Rokicki, S.; Cohen, J.; Salomon, J.A.; Fink, G. Impact of a text-messaging program on adolescent reproductive health: A cluster-randomized trial in Ghana. Am. J. Public Health 2017, 107, 298-305. [CrossRef] [PubMed]

78. Santos, M.P.; de Alencar, A.B.; Lima, S.V.M.A.; Silva, G.M.; Carvalho, C.M.D.L.; da Farre, A.G.M.C.; de Sousa, L.B. Educational pre-carnival on sexually transmitted infections with school adolescents. Rev. Enferm. UFPE Line 2017, 11, 5116. [CrossRef]

79. Siegel, D.M.; Aten, M.J.; Roghmann, K.J.; Enaharo, M. Early effects of a school-based human immunodeficiency virus infection and sexual risk prevention intervention. Arch. Pediatr. Adolesc. Med. 1998, 152, 961-970. [CrossRef]

80. Stephenson, J.; Strange, V.; Forrest, S.; Oakley, A.; Copas, A.; Allen, E.; Babiker, A.; Black, S.; Ali, M.; Monteiro, H.; et al. Pupil-Led Sex Education in England (RIPPLE Study): Cluster-randomised intervention trial. Lancet 2004, 364, 338-346. [CrossRef] 
81. Walker, D.; Gutierrez, J.P.; Torres, P.; Bertozzi, S.M. HIV prevention in Mexican schools: Prospective randomised evaluation of intervention. BMJ 2006, 332, 1189-1194. [CrossRef]

82. Yakubu, I.; Garmaroudi, G.; Sadeghi, R.; Tol, A.; Yekaninejad, M.S.; Yidana, A. Assessing the impact of an educational intervention program on sexual abstinence based on the health belief model amongst adolescent girls in Northern Ghana, a cluster randomised control trial. Reprod. Health 2019, 16, 124. [CrossRef] [PubMed] 